\title{
Potential use of GAPDH m-RNA in estimating PMI in brain tissue of albino rats at different environmental conditions
}

\author{
Hoda Abdelmagid Elghamry ${ }^{1}$, Marwa Issak Mohamed ${ }^{1}$, Fatma Mohamed Hassan ${ }^{1 *}$, Dina Sabry Abdelfattah ${ }^{2}$ and \\ Aly Gamaleldin Abdelaal ${ }^{1}$
}

\begin{abstract}
Background: Estimation of the postmortem interval (PMI) is a critical issue in forensic science. Various approaches have been used to determine the PMI including physical, biochemical and entomological methods. Most of these methods have practical limitations or provide insufficient results in certain conditions. Postmortem degradation of RNA may be a useful tool for PMl estimation if there is a correlation between the quantity of residual RNA and the elapsed time. This study aimed to evaluate the use of GAPDH mRNA quantity in the brain as a possible indicator for PMI in different environmental conditions.

Methods: Seventy-eight adult female albino rats were sacrificed by cervical dislocation. Rats were divided into five groups, the control group and 4 studied groups left after sacrificing in different conditions (ambient air at $30{ }^{\circ} \mathrm{C}$ and at $6{ }^{\circ} \mathrm{C}$, buried in sand and submerged under water). Brain samples were obtained at different intervals $(0,24,48$ and $96 \mathrm{~h}$ postmortem). The mRNA of GAPDH gene of rats' brain was quantitatively detected by qRT-PCR.

Results: The decrease of GAPDH mRNA levels with increasing PMI were observed in all study groups. There were significant negative correlations between brain GAPDH mRNA and Time intervals in rats left in air at $30{ }^{\circ} \mathrm{C}$, buried in sand and recovered from the water.
\end{abstract}

Conclusion: GAPDH mRNA in rat's brain could be a useful marker for PMl estimation in several environmental conditions.

Keywords: Postmortem interval, Rats, brain, GAPDH, mRNA

\section{Background}

Estimation of the time of death is a central question to be answered in any forensic investigation. Accurate estimation of the postmortem interval (PMI) is an essential element both in criminal and civil casework (Abdelsalam et al., 2012). It helps to determine the time of an assault, limit the number of accused persons and validate witnesses' statements. It may also affect the priority of inheritance from the order of deaths (Gomaa et al., 2013).

Since decades, many methods have been used to determine the PMI including physical, biochemical and entomological methods (Sato et al., 2015). The earliest

\footnotetext{
* Correspondence: fatmahasan.2010@yahoo.com

${ }^{1}$ Department of Forensic medicine and Clinical toxicology, Faculty of medicine, Cairo University, Cairo, Egypt

Full list of author information is available at the end of the article
}

changes after death (within the first $24 \mathrm{~h}$ postmortem) include the development and regression of rigor mortis, the progression of livor mortis and algor mortis. Although these methods are applied to assess the PMI in daily forensic work, there are still great inaccuracies and limitations (Pittner et al., 2016). Several days postmortem, forensic entomology has shown to provide valuable information about the time since death. Yet, this method is still affected by changes in weather conditions, and exposure of the body (Verma \& Paul, 2013).

Despite the extensive studies on this subject, precise PMI estimation remains a challenge. Thus, more reliable and reproducible methods to determine the PMI are required (Sato et al., 2015).

In recent years, it has been reported that the increase in PMI is associated with physical and chemical 
degradation of many biological materials in dead bodies, as protein, DNA and RNA. Generally, RNA is more susceptible to degradation than DNA and protein ( $\mathrm{Lv}$ et al., 2016). If the degree of degradation in post-mortem samples could be measured quantitatively, this would be a useful tool for precise PMI estimation (Partemi et al., 2010).

Real-time quantitative polymerase chain reaction (qRT-PCR) represents a powerful tool for the detection and quantification of mRNA. It is widely used because of its high sensitivity, good reproducibility and wide dynamic quantification range (Pfaffl, 2004).

Many mRNA markers have been studied for PMI estimation, including $\beta$-actin, GAPDH, and IL-1 $\beta$ (WenCan et al., 2014). GAPDH is one of the housekeeping genes that had shown time dependent quantitative changes with PMI in previous studies (Inoue et al. 2002; Sampaio-Silva et al. 2013 and Lv et al. 2014).

Although postmortem RNA degradation is dependent on other factors rather than time as the cause of death and environmental conditions, many studies were interested in the selection of endogenous reference biomarkers and did not progress further (Lv et al., 2016).

This study aimed to evaluate the potential use of GAPDH mRNA in estimating the PMI in rats' brain at different environmental conditions.

\section{Methods}

\section{Animal protocol}

Seventy- eight adult female albino rats weighting 120 $150 \mathrm{~g}$ obtained from the animal house, at Faculty of Medicine, Cairo University were sacrificed by cervical dislocation. Rats were divided into five groups as following; Group 0 is composed of six rats which represent the control group from where brain samples were taken immediately after the sacrifice (at the 0-time interval), each of the remaining four studied groups is composed of eighteen rats. These sacrificed rats were left in ambient air at average temperature $30^{\circ} \mathrm{C}$, buried in sand at average air temperature $30{ }^{\circ} \mathrm{C}$, submerged under water at average air temperature $30{ }^{\circ} \mathrm{C}$ and placed in refrigerator at temperature $6{ }^{\circ} \mathrm{C}$ in group $1,2,3$ and 4 respectively. Then, brain samples were obtained at 3 different postmortem time intervals; after $24 \mathrm{~h}, 48 \mathrm{~h}$ and $96 \mathrm{~h}$ (6 rats for each interval).

\section{Total RNA extraction}

Total RNA was extracted from brain using Total RNA extraction kit (GF-1, Cat. No. GF-TR-050, Malaysia). According to the manufacturer's instructions, $30 \mathrm{mg}$ of brain tissue was placed in collection tube and homogenized completely in $700 \mu \mathrm{l}$ Buffer TR then was centrifuged at $14000 \times \mathrm{g}$ for $3 \mathrm{~min}$. The lysate was transferred into Homogenization column assembled in collection tube and centrifuged at $14000 \times \mathrm{g}$ for $2 \mathrm{~min}$. The flowthrough was saved and $650 \mu \mathrm{l}$ of $80 \%$ ethanol was added to the flow-through and mixed thoroughly by pipetting. Then, the sample was transferred into RNA Binding Column assembled in collection tube and centrifuged at $10,000 \times \mathrm{g}$ for $1 \mathrm{~min}$ and flow-through was discarded. Centrifugation was repeated at $14000 \times \mathrm{g}$ for $1 \mathrm{~min}$ after adding $500 \mu \mathrm{l}$ of Wash Buffer and flow-through was discarded. $70 \mu \mathrm{l}$ of DNase I Digestion Mix was pipetted directly into the membrane of RNA Binding Column and was incubated at room temperature for $15 \mathrm{~min} .500 \mu \mathrm{l}$ of Inhibitor Removal Buffer was added and centrifuged at maximum speed for $1 \mathrm{~min}$ then flow through was discarded. $500 \mu \mathrm{l}$ of Wash Buffer was added and centrifuged twice at $10,000 \times \mathrm{g}$ for $1 \mathrm{~min}$ then flow-through was discarded. The column was centrifuged at $10,000 \times \mathrm{g}$ for $1 \mathrm{~min}$ then was placed into a new microcentrifuge tube. $60 \mu \mathrm{l}$ of RNase-free Water was added directly onto the membrane and left for $1 \mathrm{~min}$. After that, centrifugation was done at $10,000 \times \mathrm{g}$ for $1 \mathrm{~min}$. The resultant RNA was stored at $-20{ }^{\circ} \mathrm{C}$.

\section{Reverse transcription and real-time PCR}

QRT-PCR assays were performed in Step One Real Time PCR, Applied Biosystems with software version 3.1 (StepOne $^{\mathrm{in}}$, USA) detection system using (ViPrime One Step RT-qPCR 2X SyGreen Mix, HRox, Cat. No QR8602100, Malaysia). The real time PCR reaction for each sample was run in duplicate. According to manufacturer's instructions, the reactions were carried out in a total volume of $20 \mu \mathrm{L}$ containing $5 \mu \mathrm{L}$ qPCR SyGreen Mix, HRox, 2X; $1 \mu \mathrm{L}$ Forward Primer; $1 \mu \mathrm{L}$ Reverse Primer; $0.5 \mu \mathrm{L} 20$ RTase/Inhibitor Mix; $5 \mu \mathrm{L}$ Total RNA and $7.5 \mu \mathrm{L}$ RNAse free water. The thermal cycler conditions were as follows: one cycle of reverse transcription for $10 \mathrm{~min}$ at $55^{\circ} \mathrm{C}$ and initial activation for $2 \mathrm{~min}$ at $95{ }^{\circ} \mathrm{C}$ and 40 cycles of denaturing at $95{ }^{\circ} \mathrm{C}$ for $5 \mathrm{~s}$, annealing and extension at $60{ }^{\circ} \mathrm{C}$ for $1 \mathrm{~min}$.

\section{Primers for PCR \\ GAPDH (target gene)}

Forward primer: 5-'CACCCTGTTGCTGTAGCCATATTC-3'.

Reverse primer: 5'-GACATCAAGAAGGTGGTGAAGCAG-3' .

(Gene bank accession number: NG_028301.2)

\section{$\beta$-actin (reference gene)}

Forward primer: 5'-TGTTGTCCCTGTATGCCTCT-3'. Reverse primer: 5'-TAATGTCACGCACGATTTCC$3^{\prime}$.

(Gene bank accession number: J00691)

Beta actin was used as a reference gene because it is one of the most common housekeeping genes used for 
normalizing gene expression levels. It was one of the first RNAs to be used as an internal standard for qRTPCR since its transcription level remains relatively constant in response to experimental manipulation in most tissues (Li et al., 2010).

\section{Calculation of relative quantification (RQ) (relative expression)}

After the RT-PCR run, the data were expressed in Cycle threshold $(\mathrm{Ct})$. The PCR data sheet included $\mathrm{Ct}$ values of assessed gene (GAPDH) and the reference gene (Bactin). In order to measure the gene expression of certain gene, a negative control sample was used. Therefore, target gene expression was assessed and related to reference gene as follows:

$\Delta \mathrm{Ct}$ sample $=\mathrm{Ct}$ assessed gene $-\mathrm{Ct}$ reference gene.

$\Delta \Delta \mathrm{Ct}=\Delta \mathrm{Ct}$ sample $-\mathrm{Ct}$ control gene.

And finally, RQ was calculated according to the following equation:

$\mathrm{RQ}=2-(\Delta \Delta \mathrm{Ct})$.

\section{Statistical analysis}

Data were coded and entered using the statistical package SPSS version 22. Mean values \pm Standard Deviation (SD) were calculated. Comparison between groups was done using the non-parametric Kruskal-Wallis and Mann-Whitney tests. P- Values equal or less than 0.05 were considered as statistically significant. Correlations between variables were done using Spearman correlation coefficients (rs). A significant association between the sets of ranks by calculating Spearman's rank correlation coefficient (rs) is indicated by $p=0.05$, as usual. The value of rs ranges from -1 to +1 . The closer to 1 ( + or - ) the stronger the relationship.

\section{Results}

The highest degradation rate after $96 \mathrm{~h}$ was represented in group 1 (air at $30{ }^{\circ} \mathrm{C}$ ) and the lowest rate in group 4 (air at $6{ }^{\circ} \mathrm{C}$ ) (Table 1$)$.

Spearman correlation between brain GAPDH expression and Time intervals revealed significant negative correlations in groups 1,2 , and 3 (Table 2).

Comparison between the mean values of brain GAPDH of group 1, 2, and 3 (different surrounding media) at different postmortem time intervals showed statistically significant differences at $48 \mathrm{~h}$ and 96
Table 2 Spearman Correlation between brain GAPDH \& TIME intervals in different groups

\begin{tabular}{lll}
\hline & & Time (hours) \\
\hline Group 1 & $\mathbf{r}_{\mathbf{s}}$ & -0.87 \\
& $\boldsymbol{P}$ value & $0.00^{\mathrm{a}}$ \\
Group 2 & $\mathbf{r}_{\mathbf{s}}$ & -0.89 \\
& $\boldsymbol{P}$ value & $0.00^{\mathrm{a}}$ \\
Group 3 & $\mathbf{r}_{\mathbf{s}}$ & -0.66 \\
& $\boldsymbol{P}$ value & $0.00^{\mathrm{a}}$ \\
Group 4 & $\mathbf{r}_{\mathbf{s}}$ & -0.38 \\
& $\boldsymbol{P}$ value & 0.11 \\
\hline
\end{tabular}

${ }^{\mathrm{a}}$ significant $<0.05$

(Table 3) while Pairwise comparisons between GAPDH values of these intervals, showed significant difference only between group 1 and group 3 (Table 4).

Comparison between the mean values of brain GAPDH of group 1, and 4 (air at different temperatures) at different postmortem time intervals showed statistically significant differences at $48 \mathrm{~h}$ and 96 (Table 5) (Fig. 1).

\section{Discussion}

The estimation of time since death is one of the most important yet most inaccurate and contentious topics in Forensic Medicine. When calculated accurately, it has the potential to unfold many unraveled medico-legal mysteries (Garg \& Garg, 2010).

With the advances of molecular biology, postmortem degradation of nucleic acids has been suggested as an alternative to the traditional methods for PMI estimation (Gomaa et al., 2013).

In this study, we tried to simulate different scenarios which may occur following death; bodies left postmortem in the ambient air, death followed by burial in sand and submersion under water. Moreover, the air medium was examined at two different environmental temperatures; one of them was constant $\left(6^{\circ} \mathrm{C}\right)$ and the second was variable (average $30^{\circ} \mathrm{C}$ ).

The brain was selected as a target tissue because it is well isolated and protected by the skull. In addition, several studies reported the generalized stability of brain mRNA transcripts (Johnson et al. 1986; Cummings et al. 2001; Inoue et al. 2002; Miller et al. 2004; Ervin et al. 2007; Heinrich et al. 2007 and Liu et al. 2011).

Table 1 Brain GAPDH degradation rates of different groups after $96 \mathrm{~h}$

\begin{tabular}{lr}
\hline GAPDH Degradation rate (\%) & Mean \pm SD \\
\hline Group 1 (air at $30^{\circ} \mathrm{C}$ ) & $96.91 \pm 2.93$ \\
Group 2 (sand) & $91.17 \pm 6.72$ \\
Group 3 (water) & $90.37 \pm 9.59$ \\
Group 4 (air at $6{ }^{\circ} \mathrm{C}$ ) & $41.17 \pm 35.47$ \\
\hline
\end{tabular}




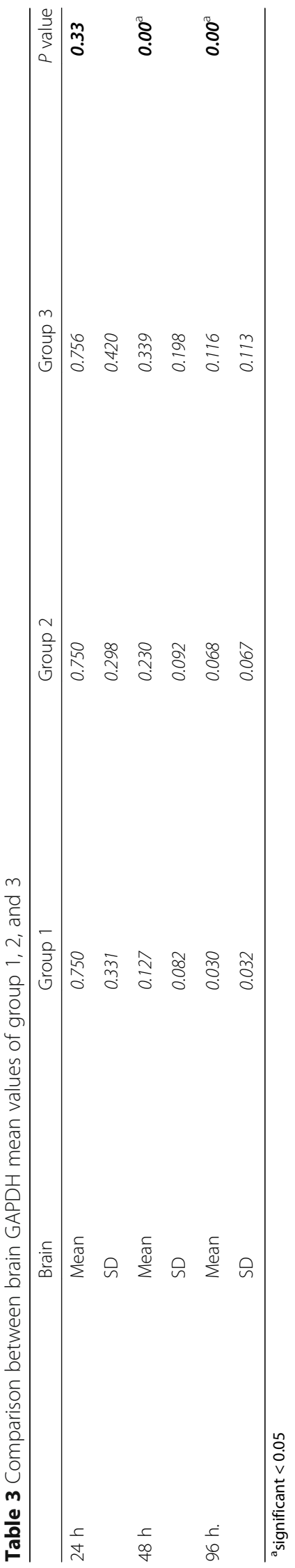


Table 4 A Pairwise Comparison between brain GAPDH of group1, 2, and 3 at $48 \mathrm{~h}$ and $96 \mathrm{~h}$

\begin{tabular}{llll}
\hline Brain & & $48 \mathrm{~h}$ & $96 \mathrm{~h}$ \\
\hline Group 1 & Group 2 & $\mathbf{0 . 0 7}$ & $\mathbf{0 . 2 6}$ \\
Group 1 & Group 3 & $\mathbf{0 . 0 2}^{\mathrm{a}}$ & $\mathbf{0 . 0 2}^{\mathrm{a}}$ \\
Group 2 & Group 3 & $\mathbf{0 . 2 6}$ & $\mathbf{0 . 2 6}$ \\
\hline
\end{tabular}

${ }^{\mathrm{a}}$ significant $<0.05$

In this study, 3 different post mortem time intervals were examined ( $24 \mathrm{~h}, 48 \mathrm{~h}$ and $96 \mathrm{~h}$ ) in addition to the fresh tissue at zero interval. Occurrence of putrefaction in rats was a limiting factor to continue for longer time intervals.

Our findings revealed that the brain GAPDH mRNA mean expression values decreased with increasing PMI in all studied groups. This decrease is attributed to the fact that RNA is degraded after death by ribonucleases already present in the cells and/or originating from bacteria or other environmental contamination and also the effect of environmental factors such as $\mathrm{pH}$, UV light and humidity (Bauer, 2007). A number of studies reported significant loss of individual mRNA transcripts with increasing PMI (Bauer et al. 2003; Barrachina et al. 2006; Durrenberger et al. 2010 and Birdsill et al. 2011).

Somewhat surprisingly, in the present study, is the increased GAPDH expression at $24 \mathrm{~h}$ in group 4 when comparing to the control group. A similar result was obtained by Deng et al. (2013), in their study on mice heart tissues at $4{ }^{\circ} \mathrm{C}$ but they do not present an explanation for this finding. We speculate that the process of dissection, brain extraction and sampling for group 4 was done while the tissues were refrigerated but in the control group this process was done while the tissues were fresh in the normal body temperature so more degradation occurred in the control relative to group (Bauer et al., 2003) resulting in "relative increasing" values in the gene expression.

Our results showed that the highest GAPDH degradation rate after $96 \mathrm{~h}$ was represented in group 1 (air at $30{ }^{\circ} \mathrm{C}$ ) and the lowest rate in group 4 (air at $6{ }^{\circ} \mathrm{C}$ ). Generally, the activity of ribonucleases is inhibited at low environmental temperature (Deng et al., 2013). Zhu et al. (2011), reported that the degradation of $\beta$-actin mRNA in brain mice was slower at $4{ }^{\circ} \mathrm{C}$ than at $37{ }^{\circ} \mathrm{C}$. Harrison et al. (1995), found that refrigeration of bodies at $8{ }^{\circ} \mathrm{C}$ post-mortem prevented a decrease in total RNA extracted from rat brain until a PMI of $96 \mathrm{~h}$.

No previously reported studies explored the gene expression of bodies buried in sand or recovered from the water. However, postmortem burial or submersion under water delays the process of decomposition than in open air (Goff, 2009). Also, Fordyce et al. (2013), stated that "informative amounts of RNA can clearly survive postmortem, conditional on tissue type and the conditions at death/burial". Thus it is likely to find differences in GAPDH degradation levels between different groups in our study.

Regarding the correlation between GAPDH expression and postmortem time intervals, our results revealed significant negative correlations in groups 1, 2 and 3.

However no previous researches proposed such study models as in groups 2 and 3, a number of studies reported the good correlation between mRNA and PMI in conditions similar to group 1, only. Ren et al. (2009), reported that the Ct values of GAPDH mRNA and $\beta$-actin mRNA of brain rats measured by real-time RT-PCR correlated well with the PMI. Also, Liu et al. (2011), reported that the changes of $\mathrm{Ct}$ values of brain $\beta$-actin mRNA of rats showed a good linear relationship with PMI at temperature $20{ }^{\circ} \mathrm{C}$ and Inoue et al. (2002) found that the $\mathrm{Ct}$ values for GAPDH mRNA in rat brains increased linearly with PMI.

In opposition to this result, Heinrich et al., (2007) and Preece \& Cairns, (2003) reported an absence of significant correlation between mRNA degradation and PMI in human brain tissue. Possible explanations for the inability to detect a clear relationship between reduced RNA quantity and the increased duration of PMI in

Table 5 Comparison between brain-GAPDH mean values of Air at $30^{\circ} \mathrm{C}$ (group1) and $6{ }^{\circ} \mathrm{C}$ (group 4)

\begin{tabular}{|c|c|c|c|c|}
\hline & Brain & Group 1 & Group 4 & $P$ value \\
\hline \multirow[t]{2}{*}{$24 \mathrm{~h}$} & Mean & 0.750 & 1.362 & 0.32 \\
\hline & SD & 0.331 & 0.842 & \\
\hline \multirow[t]{2}{*}{$48 \mathrm{~h}$} & Mean & 0.127 & 0.978 & $0.00^{\mathrm{a}}$ \\
\hline & SD & 0.082 & 0.726 & \\
\hline \multirow[t]{2}{*}{$96 \mathrm{~h}}$. & Mean & 0.030 & 0.654 & $0.00^{\mathrm{a}}$ \\
\hline & SD & 0.032 & 0.355 & \\
\hline
\end{tabular}




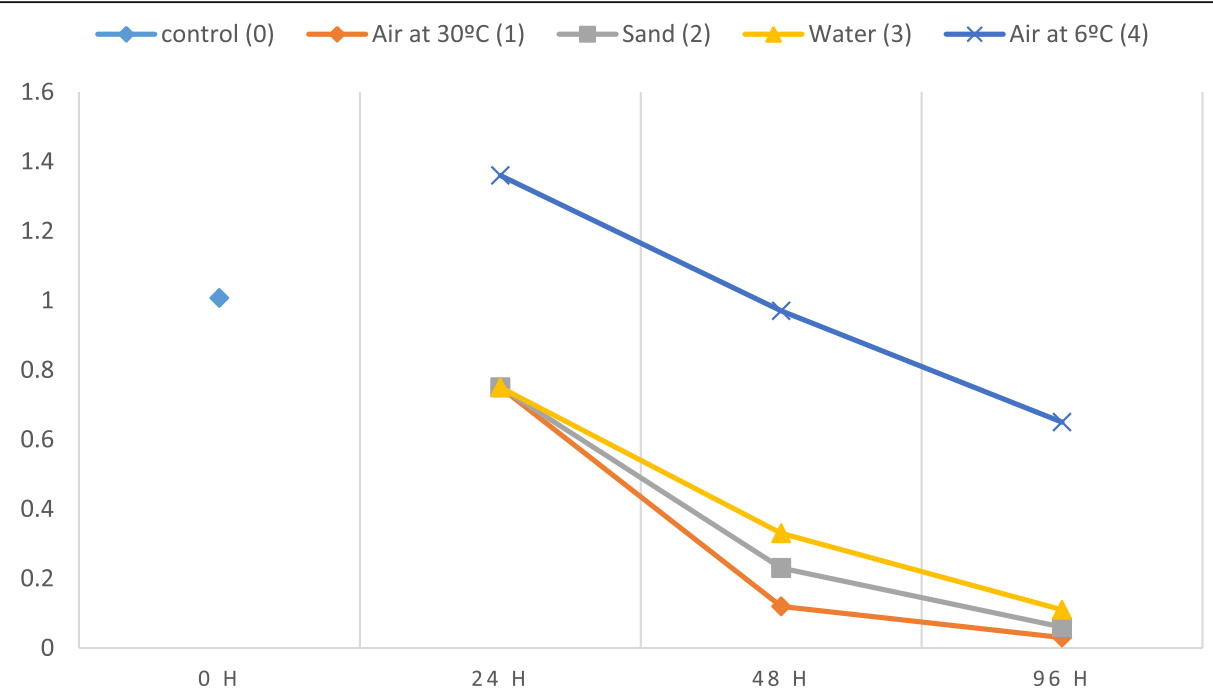

Fig. 1 GAPDH mean expression values in brain of different groups at different time intervals. The description of brain GAPDH mRNA mean expression values of different groups at different time intervals showed that the highest expression values were represented at the 0-time (control group) and the lowest values at $96 \mathrm{~h}$ with an exception in group 4 that showed higher expression level at $24 \mathrm{~h}$ relative to the control

human tissue studies include the confounding effects of greater inter-subject variability and agonal or neuropathological variables on RNA degradation (Catts et al., 2005).

Concerning the poor correlation with PMI in group 4, Deng et al. (2013), reported that $\Delta \mathrm{Ct}$ values of brain and heart HIF1-a and $\beta$-actin mRNAs showed no correlation with PMI in tissues kept at $4{ }^{\circ} \mathrm{C}$. However Bauer et al. (2003), demonstrated in their study a significant correlation between RNA degradation and PMI in stored refrigerated human brain samples for up to 5 days.

In the present study, comparison between the mean values of brain GAPDH of different groups at different conditions showed statistically significant differences at $48 \mathrm{~h}$ and $96 \mathrm{~h}$ between group 1 and 3, and also between group 1 and 4 . We suggest that temperature had the strongest influence on RNA degradation as the significant differences were observed between group 1 and 4 (different air temperatures). Also it was observed between group 1 and 3 (air and water at same ambient air temperature). Water has a higher heat capacity than air. About one unit of heat energy is needed to warm the air one degree Celsius while four times more heat energy is needed to warm the water one degree Celsius so the air temperature may be $80{ }^{\circ} \mathrm{F}\left(26.6^{\circ} \mathrm{C}\right)$ but the water temperature is usually $65^{\circ} \mathrm{F}\left(18.3{ }^{\circ} \mathrm{C}\right)$ (Office of marine program web site, 2001).

\section{Conclusion}

Our research suggests that brain GAPDH mRNA could be a valuable tool for estimating the PMI at several different environmental conditions. It could be a great addition to the current approaches of time since death estimation but certainly after inclusion of human samples in future studies and further investigations exploring the influence of various parameters (e.g. cause of death, age at death, gender and duration of agony) in order to construct an mRNA database of diagnostic significance.

\section{Abbreviations \\ C: Celsius; Ct: Cycle Threshold; DNA: Deoxyribonucleic acid; DNase I: Deoxyribonuclease inhibitor; F: Fahrenheit; GAPDH: Glyceraldehyde 3- phosphate dehydrogenase; Gm: Gram; H: Hour; HIF-1a: Hypoxia-inducible factor 1-alpha; IL-1 $\beta$ : interleukin 1 $\beta$; Min: Minute; MI: Milliliter; \\ mRNA: Messenger ribonucleic acid; PMI: Postmortem interval; qRT-PCR: Real time reverse transcription-polymerase chain reaction; RNA: Ribonucleic acid; RQ: Relative Quantification; $r_{s}$ : Spearman's rank correlation coefficient; \\ SD: Standard deviation; Sec: Second; SPSS: Statistical Package for the Social Sciences; UV: Ultraviolet; MI: Microliter}

\section{Acknowledgements}

None.

Funding

None.

Availability of data and materials

The datasets supporting the conclusions of this article are included within the article.

\section{Authors' contributions}

Prof. HE: responsible of the experimental design of the research, starting from the idea, interpretation of results and critical revision of the paper. Dr. MM: assistance in writing and final revision. Dr. FH: the experimental work and writing the paper. Prof. AA: final revision of the paper. Prof. DA: responsible for the practical part of the research. All authors read and approved the final manuscript.

\section{Ethics approval}

The experimental work was conducted after the approval of Institutional Animal Care and Use Committee, Faculty of medicine, Cairo University.

Consent for publication

Not applicable. 


\section{Competing interests}

The authors declared that they have no competing interests.

\section{Publisher's Note}

Springer Nature remains neutral with regard to jurisdictional claims in published maps and institutional affiliations.

\section{Author details}

'Department of Forensic medicine and Clinical toxicology, Faculty of medicine, Cairo University, Cairo, Egypt. ${ }^{2}$ Department of Medical biochemistry, Faculty of medicine, Cairo University, Kasr Alainy Street, Cairo 11562, Egypt.

\section{Received: 22 August 2017 Accepted: 14 November 2017}

Published online: 27 December 2017

\section{References}

Abdelsalam HF, Shaat EA, Abdelaziz MH, Sheta AA, Hussein HA (2012) Estimation of postmortem interval using thanatochemistry and postmortem changes. Alex J Med 48:335-344

Barrachina M, Castano E, Ferrer I (2006) TagMan PCR assay in the control of RNA normalization in human postmortem brain tissue. Neurochem Int 49:276-284 Bauer M (2007) RNA in forensic science. Forensic Sci Int Genet 1:69-74

Bauer M, Gramlich I, Polzin S, Patzelt D (2003) Quantification of mRNA degradation as possible indicator of postmortem interval —a pilot study. Legal Med 5:220-227

Birdsill AC, Walker DG, Lue L, Sue LI, Beach TG (2011) Postmortem interval effect on RNA and gene expression in human brain tissue. Cell Tissue Bank 12(4): $311-318$

Catts VS, Catts SV, Fernandez HR, Taylor JM, Coulson EJ, Lutze-Mann LH (2005) A microarray study of post-mortem mRNA degradation in mouse brain tissue. Mol Brain Res 138:164-177

Cummings TJ, Strum JC, Yoon LW, Szymanski MH, Hulette CM (2001) Recovery and expression of messenger RNA from postmortem human brain tissue. Mod Pathol 14:1157-1161

Deng W, Lv M, Wang L, Bai P, Liang W, Zhang L (2013) mRNA degradation pattern analysis in post-mortem normalized using the DNA. Forensic Sci Int Genet Suppl Ser 4:266-267

Durrenberger PF, Fernando S, Kashefi SN, Ferrer I, Hauw JJ, Seilhean D, Smith C, Walker R, Al-Sarraj S, Troakes C, Palkovits M, Kasztner M, Huitinga I, Arzberger T, Dexter DT, Kretzschmar H, Reynolds R (2010) Effects of antemortem and postmortem variables on human brain mRNA quality: a brain net Europe study. J Neuropathol Exp Neurol 69:70-81

Ervin JF, Heinzen EL, Cronin KD, Goldstein D, Szymanski MH, Burke JR, WelshBohmer KA, Hulette CM (2007) Postmortem delay has minimal effect on brain RNA integrity. J Neuropathol Exp Neurol 66:1093-1099

Fordyce SL, Kampmann ML, Doorn NL, Gilbert MT (2013) Long-term RNA persistence in postmortem contexts. Investig Genet 4:1-7

Garg SP, Garg V (2010) Serum enzymes changes after death \& its correlation with time since death. J Ind Acad Forensic Med 32(4):355-357

Goff ML (2009) Early post-mortem changes and stages of decomposition in exposed cadavers. Exp Appl Acarol 49:21-36

Gomaa MS, Abd El-Khalek AM, Sameer MM (2013) The relationship between the postmortem interval and the DNA degradation in brain and liver of adult albino rats. J Am Sci 9(5):535-540

Harrison PJ, Heath PR, Eastwood SL, Burnet PW, McDonald B, Pearson RC (1995) The relative importance of premortem acidosis and postmortem interval for human brain gene expression studies: selective mRNA vulnerability and comparison with their encoded proteins, Neurosci. Lett 200:151-154

Heinrich M, Matt K, Lutz-Bonengel S, Schmidt U (2007) Successful RNA extraction from various human post-mortem tissues. Int J Legal Med 121:136-142

Inoue H, Kimura A, Tuji T (2002) Degradation profile of mRNA in a dead rat body: basic semi-quantification study. Forensic Sci Int 130:127-132

Johnson SA, Morgan DG, Finch CE (1986) Extensive postmortem stability of RNA from rat and human brain. J Neurosci Res 16:267-280

Li Z, Yang L, Wang J, Shi W, Pawar RA, Liu Y, Xu C, Cong W, Hu Q, Lu T, Xia F, Guo W, Zhao M, Zhang Y (2010) B-Actin is a useful internal control for tissuespecific gene expression studies using quantitative real-time PCR in the halfsmooth tonque sole Cynoglossussemilaevis challenged with LPS or Vibrio anguillarum. Fish Shellfish Immunol 29:89-93
Liu YL, Ma KJ, Li WC, Xu HM, Xue AM, Shen YW, Zhou YQ, Zhao ZQ (2011) Estimation of early postmortem interval using beta-actin mRNA in rat's brain, heart and kidney. Fa Yi Xue Za Zhi 27(1):5-8

Lv Y, Ma K, Zhang H, He M, Zhang P, Shen Y, Jiang N, Ma D, Chen L (2014) A time course study demonstrating mRNA, microRNA, $18 \mathrm{~S}$ rRNA, and U6 snRNA changes to estimate PMI in deceased Rat's spleen. J Forensic Sci 59(5):1286-1294

Lv YH, Ma JL, Pan H, Zhang H, Li WC, Xue AM, Wang HJ, Ma KJ, Chen L (2016) RNA degradation as described by a mathematical model for postmortem interval determination. J Forensic Legal Med 44:43-52

Miller CL, Diglisic S, Leister F, Webster M, Yolken RH (2004) Evaluating RNA status for RT-PCR in extracts of postmortem human brain tissue. BioTechniques 36: 628-633

Office of marine program web site (2001) Estuarine Science: Temperature: Why does the air warm faster than the water? Available from: http://www.omp. gso.uri.edu/ompweb/doee/science/physical/chtemp6.htm. [Accessed 2 Dec 2016]

Partemi S, Berne PM, Batlle M, Berruezo A, Mont L, Riuro H, Roig E, Brugada J, Brugada R, Oliva A (2010) Analysis of mRNA from human heart tissue and putative application in forensic molecular pathology. Forensic Sci Int 203:99105

Pfaffl MW (2004) Quantification strategies in real-time PCR. In: Bustin SA (ed) A-Z of quantitative PCR. International University Line, San Diego, pp 78-112

Pittner S, Ehrenfellner B, Monticelli FC, Zissler A, Sänger AM, Stoiber W Steinbacher P (2016) Postmortem muscle protein degradation in humans as a tool for PMl delimitation. Int J Legal Med 130(6):1547-1555

Preece P, Cairns NJ (2003) Quantifying mRNA in postmortem human brain: influence of gender, age at death, postmortem interval, brain pH, agonal state and inter-lobe mRNA variance. Brain Res Mol Brain Res 118:60-71

Ren GM, Liu J, Wang YY (2009) The degradation of housekeeping mRNA in dead rats by real-time RT-PCR. Fa Yi Xue Za Zhi 25(1):33-36

Sampaio-Silva F, Magalhaes T, Carvalho F (2013) Profiling of RNA degradation for estimation of postmortem interval. PLoS One 8(2):1-8

Sato T, Zaitsu K, Tsuboi K, Nomura M, Kusano M, Shima N, Abe S, Ishii A, Tsuchihashi H, Suzuki K (2015) A preliminary study on postmortem interval estimation of suffocated rats by GC-MS/MS-based plasma metabolic profiling Anal Bioanal Chem 407(13):3659-3665

Verma K, Paul R (2013) Assessment of post mortem interval, (PMI) from forensic Entomotoxicological studies of larvae and flies. Entomol Ornitho Herpetol 1(1):1-4

Wen-Can L, Kai-Jun M, Ye-Hui L, Ping Z, Hui P, Heng Z, Hui-Jun W, Duan M, Long C (2014) Postmortem interval determination using 18S-rRNA and microRNA. Sci Justice 54(4):307-310

Zhu Y, Dong YC, Liang WB, Zhang L (2011) Relationship between RNA degradation and postmortem interval in mice. Fa Yi Xue Za Zhi 27(3):161163177

\section{Submit your manuscript to a SpringerOpen ${ }^{\circ}$ journal and benefit from:}

- Convenient online submission

- Rigorous peer review

- Open access: articles freely available online

High visibility within the field

- Retaining the copyright to your article

Submit your next manuscript at $\boldsymbol{\nabla}$ springeropen.com 